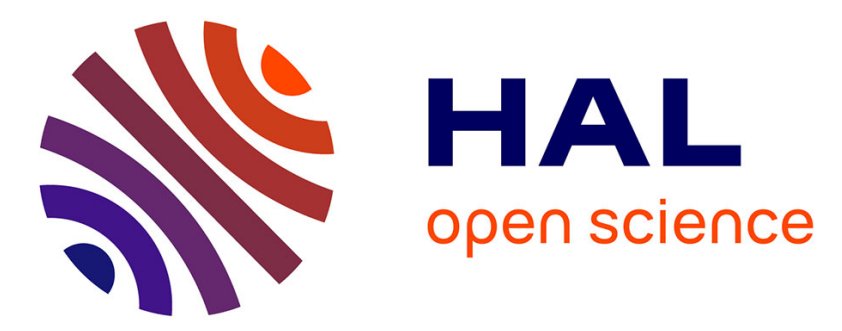

\title{
Sequestration of Radionuclides Radium-226 and Strontium-90 by Cyanobacteria Forming Intracellular Calcium Carbonates
}

Neha Mehta, Karim Benzerara, Benjamin Kocar, Virginie Chapon

\section{To cite this version:}

Neha Mehta, Karim Benzerara, Benjamin Kocar, Virginie Chapon. Sequestration of Radionuclides Radium-226 and Strontium-90 by Cyanobacteria Forming Intracellular Calcium Carbonates. Environmental Science and Technology, 2019, 53 (21), pp.12639-12647. 10.1021/acs.est.9b03982 . cea02374665

\section{HAL Id: cea-02374665 https://hal-cea.archives-ouvertes.fr/cea-02374665}

Submitted on 11 Dec 2019

HAL is a multi-disciplinary open access archive for the deposit and dissemination of scientific research documents, whether they are published or not. The documents may come from teaching and research institutions in France or abroad, or from public or private research centers.
L'archive ouverte pluridisciplinaire HAL, est destinée au dépôt et à la diffusion de documents scientifiques de niveau recherche, publiés ou non, émanant des établissements d'enseignement et de recherche français ou étrangers, des laboratoires publics ou privés. 
1 Sequestration of radionuclides Radium-226 and Strontium-90 by 2 cyanobacteria forming intracellular calcium carbonates

3 Neha Mehta ${ }^{1}$, Karim Benzerara ${ }^{2 *}$, Benjamin D. Kocar ${ }^{1,3 *}$, Virginie Chapon ${ }^{4}$

$4 \quad{ }^{1,3}$ Department of Civil and Environmental Engineering, Massachusetts Institute of Technology, Cambridge,

5 Massachusetts 02139, United States

$62 \quad{ }^{2}$ Sorbonne Université, Muséum National d'Histoire Naturelle, UMR CNRS 7590, Institut de Minéralogie, de

7 Physique des Matériaux et de Cosmochimie, IMPMC, 75005 Paris, France

8 3. Exponent, Inc. 1055 E. Colorado Blvd, Suite 500. Pasadena, California 91106, United States.

$9 \quad{ }^{4}$ CEA, CNRS, Aix-Marseille Université, UMR 7265 Biosciences and Biotechnologies Institute of Aix-

10 Marseille, 13108 Saint-Paul-lez-Durance, France.

$11 *$ Corresponding Authors

12 Email: bkocar@exponent.com; karim.benzerara@sorbonne-universite.fr

ABSTRACT: ${ }^{226} \mathrm{Ra}$ is a naturally occurring radionuclide with a half-life of $1600 \mathrm{y}$. In contrast, ${ }^{90} \mathrm{Sr}$ is a radionuclide of sole anthropogenic origin, produced by nuclear fission reactions and has a half-life of $29 \mathrm{y}$; each of these radionuclides poses potential threats to human and ecosystem health. Here, the cyanobacterium G. lithophora, capable of forming intracellular amorphous calcium carbonate inclusions, was investigated for its ability to uptake ${ }^{226} \mathrm{Ra}$ and ${ }^{90} \mathrm{Sr}$. In BG-11 medium, G. lithophora accumulated $3.9 \mu \mathrm{g} \mathrm{g}^{-1}{ }^{226} \mathrm{Ra}$ within $144 \mathrm{~h}$ and $47.9 \mathrm{ng} \mathrm{g}^{-1}{ }^{90} \mathrm{Sr}$ within $1 \mathrm{~h}$, corresponding to $\sim 99 \%$ removal of trace radionuclides. The presence of high concentration $\mathrm{Ca}^{2+}$ in the background media solution did not inhibit ${ }^{90} \mathrm{Sr}$ and ${ }^{226} \mathrm{Ra}$ uptake by G. lithophora. In contrast, dead biomass of G. lithophora accumulated $0.8 \mu \mathrm{g} \mathrm{g}^{-1}{ }^{226} \mathrm{Ra}$ and $8.87 \mathrm{ng} \mathrm{g}^{-1}{ }^{90} \mathrm{Sr}$. Moreover, Synechocystis, a nonbiomineralizing cyanobacteria removed only $14 \%$ and $25 \%$ of ${ }^{226} \mathrm{Ra}$ and ${ }^{90} \mathrm{Sr}$, respectively. This suggested that sequestration of ${ }^{90} \mathrm{Sr}$ and ${ }^{226} \mathrm{Ra}$ was not intrinsic to all cyanobacteria but was likely a specific biological trait of G. lithophora related to the formation of intracellular amorphous Ca-carbonates. The unique ability of G. lithophora to uptake ${ }^{90} \mathrm{Sr}$ and ${ }^{226} \mathrm{Ra}$ at 
high rates makes it an attractive candidate for further studies involving bioremediation of these radionuclides.

(1)

Radlonuclide $(x)$

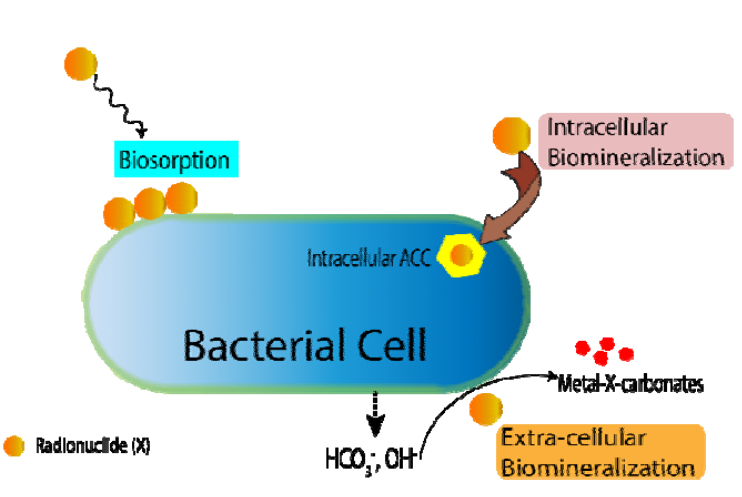

\section{TOC image}

\section{Introduction}

Cyanobacteria are a phylogenetically and ecologically diverse group of photosynthetic bacteria, playing a vital role in the global cycling of numerous elements such as carbon $(\mathrm{C})$, calcium $(\mathrm{Ca})$ and phosphorus $(\mathrm{P})^{1}$. In particular, their impact on the global carbon cycle is of significant interest as they sequester atmospheric $\mathrm{CO}_{2}$ into organic carbon and biogenic calcium carbonates $\left(\mathrm{CaCO}_{3}\right)$ through calcification ${ }^{2}$. In cyanobacteria, this process has long been considered as extracellular and non-biologically controlled. However, this paradigm was challenged by the recent discovery of several species of cyanobacteria forming intracellular amorphous calcium carbonate (ACC) inclusions in very diverse environments. ${ }^{3}$ Couradeau et al. first described this intracellular calcification in the cyanobacterium Gloeomargarita lithophora, isolated from an alkaline freshwater lake Alchichica microbialite, Mexico ${ }^{4}$. These ACC inclusions measured several hundreds of nanometers in diameter, were poorly crystalline and were composed of $\mathrm{CO}_{3}$ and $\mathrm{Ca}-\mathrm{Mg}-\mathrm{Sr}-$ 
$\mathrm{Ba}$, with $\mathrm{Ba} / \mathrm{Ca}$ and $\mathrm{Sr} / \mathrm{Ca}$ atomic ratios in inclusions higher by factors of 1370 and 90 respectively relative to the solutions in which cells grew ${ }^{3,4}$. Recently, it was confirmed that cyanobacteria capable of forming intracellular ACC contained a much higher content of alkaline earth elements (AEE) than all other cyanobacteria ${ }^{5}$. In addition to intracellular ACC inclusions, G. lithophora also forms intracellular polyphosphate inclusions (PolyP), polymers of orthophosphate which may serve as reserves of $\mathrm{P}$ and/or energy for cells ${ }^{6}$. Using stable isotopes, Cam et al. showed that G. lithophora preferentially accumulated Ba over Sr and finally Ca within intracellular PolyP and ACC. Currently, the origin of such a surprising selectivity remains unclear. The proven ability of G. lithophora to selectively sequester $\mathrm{Sr}$ over $\mathrm{Ca}$ within intracellular inclusions provides an intriguing microbial framework to examine if this ability extends to radioactive AEE such as radium $\left({ }^{226} \mathrm{Ra}\right)$ and radio-strontium $\left({ }^{90} \mathrm{Sr}\right)$. In the environment, ${ }^{90} \mathrm{Sr}$ and ${ }^{226} \mathrm{Ra}$ are present at trace concentrations, along with excess dissolved $\mathrm{Ca}$. Whether the observed selective accumulation of AEE is extended to ${ }^{90} \mathrm{Sr}$ and ${ }^{226} \mathrm{Ra}$ at such low concentrations and in the presence of high concentrations of Ca remains to be explored.

Radium-226 is a naturally occurring radioactive alkaline earth element (AEE) with a half-life of $1600 \mathrm{y}$. It is one of the dominant soluble radionuclides present in groundwater ${ }^{7}$. In the United States, ${ }^{226} \mathrm{Ra}$ activity in drinking water is regulated at $0.2 \mathrm{~Bq} \mathrm{~L}^{-18}$. Potential exposure to Ra could originate from the disposal and management of large volumes of Rabearing waste streams associated with uranium mining, phosphate mining and milling operations, coal mining and power plants, and conventional and unconventional oil and gas extraction ${ }^{9}$. The Ra content of these waste streams can range from 100-1200 $\mathrm{Bq} \mathrm{L}^{-1}$, which far exceeds the regulatory limit of $2.2 \mathrm{~Bq} \mathrm{~L}^{-1} \mathrm{Ra}$ in effluent waste stream ${ }^{10}$. During disposal 
and storage of relatively large volumes of these streams, leaching of Ra (and other toxic elements) could result in contamination of terrestrial and subsurface aquatic environments $^{11,12}$.

In contrast, radio-Strontium $\left({ }^{90} \mathrm{Sr}\right)$ is a radionuclide of sole anthropogenic origin produced by nuclear fission reactions. With its long half-life of 29 years, ${ }^{90} \mathrm{Sr}$ persists sufficiently long in the environment to warrant health concerns. The main sources of ${ }^{90} \mathrm{Sr}$ in the environment are the atmospheric tests of nuclear weapons conducted from 1945 to 1980's and nuclear accidents, such as Fukushima and Chernobyl ${ }^{13,14}$. Measured ${ }^{90} \mathrm{Sr}$ specific activity in the surface waters adjacent to the Fukushima Daiichi Nuclear Power Plant varied between $0.2-400 \mathrm{kBq} \mathrm{m}^{-3}$, which were about 4 orders of magnitude greater than the preaccident level $\left(1 \mathrm{~Bq} \mathrm{~m}^{-3}\right)^{15}$. Strontium is very soluble, highly mobile and is bioavailable in the environment. Its soluble form, $\mathrm{Sr}^{2+}$ can be transferred from contaminated soils and water into living organisms through the food chain. A chemical analog of $\mathrm{Ca}^{2+},{ }^{90} \mathrm{Sr}^{2+}$ concentrates in bone tissues in the human body, increasing the probability of bone cancer after accumulation and prolonged exposure ${ }^{16}$.

Several physiochemical strategies have been developed for decontamination of ${ }^{226} \mathrm{Ra}$ and ${ }^{90} \mathrm{Sr}$ from effluent waste streams. However, in many cases their application is limited due to economic constraints ${ }^{17}$. In addition, the presence of high concentrations of $\mathrm{Ca}$ and other co-contaminants often present within waste streams limits the selective removal of ${ }^{226} \mathrm{Ra}$ and ${ }^{90} \mathrm{Sr}$ using the traditional schemes ${ }^{18,19}$. On the other hand, bioremediation strategies are gaining significant interest owing to their relative cost-effectiveness and ecofriendliness ${ }^{20-22}$. Various types of organisms including fungi, algae, cyanobacteria, and phytoplankton have been reported to retain ${ }^{226} \mathrm{Ra}$ and ${ }^{90} \mathrm{Sr}^{9,23}$. Different pathways of 
sequestration can be involved. ${ }^{226} \mathrm{Ra}$ and ${ }^{90} \mathrm{Sr}$ can adhere to the surface of living and dead cells. Ligands (carboxyl, amine, hydroxyl, phosphate, and sulfhydryl groups) present in the cell membrane of both Gram-positive and Gram-negative bacteria can bind positively charged metals through adsorption ${ }^{24}$. Some examples of such microorganisms adsorbing ${ }^{226} \mathrm{Ra}$ include dead microbial biomass of Pseudomonas aeruginosa, Nostoc carneum, Nostoc insulare, Oscillatoria geminanat, Spirullina laxissima, Pseudomonas fluorescens, Streptomyces nives, and mixed bacterial cultures from activated wastewater sludges ${ }^{23,25}$. The dead biomass of bacterial strains isolated from areas with a high level of natural radiation, such as Citrobacter freundii, Chromobacterium, Chryseobacterium, and Corynebacterium also have been shown to adsorb ${ }^{226} \mathrm{Ra}^{26}$. In the case of ${ }^{90} \mathrm{Sr}$, studies have often been performed using stable $\mathrm{Sr}$ isotopes to examine the ${ }^{90} \mathrm{Sr}$ remediation potential of an organism. Some organisms such as the algae Scenedesmus spinosus and Oedogonium sp. Nak 1001, the cyanobacteria Oscillatoria homogenea and Stigonema ocellatum NIES-2131, and the aquatic plant Egeria densa We2 have been reported to show high stable-Sr adsorption $^{27,28}$. In addition to adsorption, many types of microorganisms may accumulate ${ }^{226} \mathrm{Ra}$ and ${ }^{90} \mathrm{Sr}$ within extracellularly or intracellularly precipitated biogenic minerals. The formation of biominerals occurs in response to localized changes in cellular or extracellular microenvironments. To our knowledge, there is no known micro-organism which has been reported to biomineralize ${ }^{226} \mathrm{Ra}$. Several organisms have been screened for their ability to (co)-precipitate Sr. For example, the microalga Chlorella vulgaris, soil bacterium Sporosarcina pasteurii and the bacterium Halomonas sp. induce co-precipitation of strontianite $\left(\mathrm{SrCO}_{3}\right)$ within extracellularly precipitated $\mathrm{CaCO}_{3}$ mineral phase; the desmid Closterium moniliferum forms celestite $\left(\mathrm{SrSO}_{4}\right)$ within its vacuole by concentrating 
117 preferentially $\mathrm{Sr}$ and $\mathrm{Ba}$ over $\mathrm{Ca}^{29-32}$. More recently, Cam et al. showed stable-Sr is 118 selectively accumulated within intracellular ACC and PolyP inclusions in the 119 cyanobacterium G. lithophora ${ }^{33}$. Owing to selectivity for Sr compared to Ca, G. lithophora 120 forms carbonate with higher $\mathrm{Sr}$ content in comparison to other bacteria forming extracellular 121 carbonates. This means that the mass of the decontamination by products will therefore be 122 lower which may offer a cost advantage. Some of the non-photosynthetic bacteria which are 123 known to precipitate $\mathrm{CaCO}_{3}$ efficiently, exhibit lower Sr removal efficiency in comparison 124 to G. lithophora. For example, S. pasteurii removes upto 59\% of Sr from the solution 125 whereas G. lithophora removes $100 \%$ of $\mathrm{Sr}$ from the solution ${ }^{32,33}$. Despite screening of several organisms for removal of ${ }^{90} \mathrm{Sr}$ and ${ }^{226} \mathrm{Ra}$, these studies have not demonstrated their potential for use in bioremediation. Indeed, research on ${ }^{90} \mathrm{Sr}$ bioremediation has mostly utilized stable-Sr isotope as an analog of ${ }^{90} \mathrm{Sr}$ and at relatively high concentrations. Owing to the radiotoxicity of ${ }^{90} \mathrm{Sr}$, it is unclear whether the results demonstrated using stable $\mathrm{Sr}$ isotopes would be replicated to the same extent in presence of ${ }^{90} \mathrm{Sr}$. Further, ${ }^{226} \mathrm{Ra}$ and ${ }^{90} \mathrm{Sr}$ removed from solution through adsorption to biomass is prone to rapid desorption upon changes in aqueous chemistry. Moreover, biomass is not selective and other divalent cations (e.g. $\mathrm{Ca}, \mathrm{Ba}$ ), which are often present at relatively high

134 concentrations in ${ }^{226} \mathrm{Ra}$ and/or ${ }^{90} \mathrm{Sr}$ contaminated aqueous environments, may outcompete ${ }^{226} \mathrm{Ra}$ and/or ${ }^{90} \mathrm{Sr}$ for binding sites, resulting in low removal efficiency ${ }^{22,24}$. Thus, 136 effectiveness of ${ }^{226} \mathrm{Ra}$ and ${ }^{90} \mathrm{Sr}$ bioremediation strategies will be dictated by (micro)137 organisms capability to selectively remove the radionuclide at trace concentration in the 138 presence of competing elements while also tolerating ionizing radiation. 

on sequestration of ${ }^{226} \mathrm{Ra}$ and ${ }^{90} \mathrm{Sr}$ at trace concentrations is evaluated. We selected $G$. lithophora to evaluate as a potential bioremediation tool for removing ${ }^{90} \mathrm{Sr}$ and ${ }^{226} \mathrm{Ra}$ from solution for several reasons. Because of the photoautotrophic lifestyle of cyanobacteria, $G$. lithophora may exhibit tolerance to substantial levels of ionizing radiation ${ }^{34}$. Moreover, unlike other (micro)organisms, G. lithophora has been shown to preferentially sequester $\mathrm{Sr}$ over $\mathrm{Ca}$ within intracellular ACC and PolyP inclusions, despite their chemical similarity.

These characteristics make G. lithophora a promising candidate for bioremediation of ${ }^{226} \mathrm{Ra}$ and ${ }^{90} \mathrm{Sr}$. Proving the ability of G. lithophora to sequester ${ }^{226} \mathrm{Ra}$ and ${ }^{90} \mathrm{Sr}$ through a novel (co)-precipitation pathway will illustrate its promise for use in bioremediation efforts; also, owing to its widespread ecological distribution ${ }^{35}$, its cultivability and the availability of its genome sequence ${ }^{36}$, G. lithophora serves as an ideal model organism for examining underlying biochemical processes responsible for bioaccumulation of radioactive AEE in microbes. Accordingly, the goals of the current study are 1) to investigate and quantify ${ }^{226} \mathrm{Ra}$ and ${ }^{90} \mathrm{Sr}$ uptake by G. lithophora using laboratory batch incubations, and 2) to identify retention mechanism of ${ }^{226} \mathrm{Ra}$ and ${ }^{90} \mathrm{Sr}$ by G. lithophora.

\section{EXPERIMENTAL SECTION:}

\section{Incubations and Culture Conditions}

The cyanobacterial strain G. lithophora was obtained from Institut de Minéralogie, de Physique des Matériaux et de Cosmochimie, IMPMC, Paris, France and cultured in the BG-

15911 medium at $30^{\circ} \mathrm{C}$ under continuous light $\left(5-10 \mu \mathrm{mol} \mathrm{m} \mathrm{m}^{-1}\right)$ as described by Moreira et al.

$160{ }^{36}$. The BG-11 medium contained $17.6 \times 10^{-3} \mathrm{M} \mathrm{NaNO}_{3}, 0.23 \times 10^{-3} \mathrm{M} \mathrm{K}_{2} \mathrm{HPO}_{4}, 0.3 \times 10^{-3} \mathrm{M}$ $161 \mathrm{MgSO}_{4}, 2.5 \times 10^{-4} \mathrm{M} \mathrm{CaCl}_{2}, 3.1 \times 10^{-5} \mathrm{M}$ citric acid, $2 \times 10^{-5} \mathrm{M}$ ferric ammonium citrate, $3 \times 10^{-6}$ $162 \mathrm{M}$ ethylenediaminetetraacetic acid (EDTA), $5 \times 10^{-4} \mathrm{M} \mathrm{NaHCO}_{3}$, and trace metals ${ }^{37}$. The 
optical density (OD) of the suspensions was measured at $730 \mathrm{~nm}$; based on the previous work by Cam et $a .^{33}$, the relationships between OD, cell density and cell dry mass of $G$. lithophora, were estimated as $9 \times 10^{7}$ cells. $\mathrm{mL}^{-1} \mathrm{OD}$ unit ${ }^{-1}$ and $3.65 \times 10^{-4} \mathrm{~g}$ of dry mass. OD unit ${ }^{-1} \cdot \mathrm{mL}^{-1}$.

\section{${ }^{226}$ Ra uptake by G. lithophora}

${ }^{226} \mathrm{Ra}$ uptake was measured during the growth stage of $G$. lithophora cultures, which were started at low cell density $\left(\mathrm{OD}_{\mathrm{t}=0}=0.039 \pm 0.01\right)$. Pre-cultures used for inoculation were centrifuged at $5000 \mathrm{~g}$ for $15 \mathrm{~min}$ and the cell pellets were re-suspended in BG-11 amended with ${ }^{226} \mathrm{Ra}$ and total $\mathrm{Ca}$ as chloride salts at concentrations of $7.5 \times 10^{-10} \mathrm{M}$ (i.e. $6153 \mathrm{~Bq} \mathrm{~L}^{-1}$ ${ }^{226} \mathrm{Ra}$ ) and $6.32 \times 10^{-4} \mathrm{M}$, respectively and buffered at $\mathrm{pH} 8$ using HEPES buffer. Triplicate incubations were performed. Three types of controls were included in the experimental design:1) an abiotic control consisting of BG-11 medium amended with $7.5 \times 10^{-10} \mathrm{M}$ of ${ }^{226} \mathrm{Ra}$ and $6.32 \times 10^{-4} \mathrm{M}$ of $\mathrm{Ca}^{2+} .2$ ) Inactivated cells control consisted of $\mathrm{G}$. lithophora cells cultured in BG-11, killed by gamma irradiation $\left({ }^{60} \mathrm{Co}\right.$ source, $\left.55 \mathrm{~h}\right)$ and re-suspended at an OD of 1 in fresh BG-11 medium with $5.2 \times 10^{-10} \mathrm{M}$ (i.e. $5600 \mathrm{~Bq} \mathrm{~L}^{-1}$ ) of ${ }^{226} \mathrm{Ra}$ and $2.5 \times 10^{-4}$ $\mathrm{M}$ of $\mathrm{Ca}^{2+}$. This control was used to quantify ${ }^{226} \mathrm{Ra}$ uptake by dead G. lithophora biomass and adsorption of ${ }^{226} \mathrm{Ra}$ to walls of the culture vessel. 3) Living cells of Synechocystis sp. PCC 6803 (obtained from Pasteur Collection of Cyanobacteria) cultured in BG-11 and amended with $5.2 \times 10^{-10} \mathrm{M}$ (i.e. $5600 \mathrm{~Bq} \mathrm{~L}^{-1}$ ) of ${ }^{226} \mathrm{Ra}$ and $2.5 \times 10^{-4} \mathrm{M}$ of $\mathrm{Ca}^{2+}$. This species has been shown to be unable to biomineralize intracellular $\mathrm{ACC}^{3}$. The OD of Synechocystis sp. PCC 6803 cultures at the start of experiment was equal to $0.02 \pm 0.002$.

Dissolved $\mathrm{Ca}^{2+}$ concentration and residual ${ }^{226} \mathrm{Ra}$ activity in solution were measured in all solutions as a function of time. For dissolved $\mathrm{Ca}^{2+}$ measurements, $100 \mu$ of the culture 
were mixed with $2 \mathrm{ml}$ of standard BG-11 medium and were filtered on $0.22 \mu \mathrm{m}$ PES syringe filters. Filtrates were acidified with $3 \mathrm{~mL}$ of $3 \% \mathrm{HNO}_{3}$. Dissolved $\mathrm{Ca}^{2+}$ concentrations were measured using an Agilent Inductively Coupled Optical Emission Spectrometer (ICP-OES). Concentration of $\mathrm{Ca}^{2+}$ was also measured in the reagent blank $(2 \mathrm{~mL}$ BG-11 $+3 \mathrm{~mL} 3 \%$ $\mathrm{HNO}_{3}$ ) to eliminate background signal.

For measurement of residual ${ }^{226} \mathrm{Ra}$ in solution, $500 \mu \mathrm{l}$ of the culture were mixed with $2 \mathrm{ml}$ of standard BG-11 medium and were filtered on $0.22 \mu \mathrm{m}$ PES syringe filters. Filtrates were acidified with $3 \% \mathrm{HNO}_{3}$ and counted using a Canberra High Purity Germanium Detector (HPGe) Gamma Spectrometer. Energy and efficiency calibration of gamma spectroscopy was performed using a mixed multi-nuclide Eckert \& Ziegler ${ }^{\mathrm{TM}}$ aqueous gamma standard. ${ }^{226} \mathrm{Ra}$ was directly measured from its gamma peak at $186.5 \mathrm{keV}$.

\section{${ }^{90}$ Sr uptake by $\mathrm{G}$. lithophora}

${ }^{90} \mathrm{Sr}$ uptake by G. lithophora was studied following a different strategy. In this case, cell suspensions of G. lithophora at high cell density were used. The high cell density of the culture is expected to provide a faster uptake of ${ }^{90} \mathrm{Sr}$. Cells previously grown in standard BG-11 to an OD of 1 were centrifuged at $8500 \mathrm{~g}$ for $10 \mathrm{~min}$ and the cell pellets were resuspended in standard BG-11 at an OD of 0.5 (i.e. $0.1825 \mathrm{~g} \mathrm{~L}^{-1}$ ). The suspensions were then amended with $8.8 \times 10^{-11} \mathrm{M}$ of ${ }^{90} \mathrm{Sr}$ (i.e. $\left.4 \times 10^{4} \mathrm{~Bq} \mathrm{~L}^{-1}\right)$. Three types of controls were included in the experiment: 1) an abiotic control consisting of BG-11 medium amended with $8.8 \times 10^{-11} \mathrm{M}$ of ${ }^{90} \mathrm{Sr}$. 2) Inactivated cells control consisting in G. lithophora cells grown in BG-11 medium, freeze-dried and killed by autoclaving $\left(121^{\circ} \mathrm{C}\right.$ in $\left.20 \mathrm{~min}\right)$. Dried biomass was suspended at $0.2 \mathrm{~g} \mathrm{~L}^{-1}$ in BG-11 amended with $8.8 \times 10^{-11} \mathrm{M}$ of ${ }^{90} \mathrm{Sr}$. The protocol of cell inactivation was different in this case than for experiments with ${ }^{226} \mathrm{Ra}$. However, both 
approaches were similarly efficient at providing dead cell controls which eventually show low sorption capabilities of ${ }^{226} \mathrm{Ra}$ and ${ }^{90} \mathrm{Sr}$ as detailed later in the manuscript 3) Living cells of Synechocystis sp. PCC 6803 grown in BG-11, collected by centrifugation at $8500 \mathrm{~g}$ for 10 min, re-suspended in fresh BG-11 at an OD of 0.5 and amended with $8.8 \times 10^{-11} \mathrm{M}$ of ${ }^{90} \mathrm{Sr}$. Triplicate incubations were performed for all experimental treatments. Total ${ }^{90} \mathrm{Sr}$ and residual ${ }^{90} \mathrm{Sr}$ in solution were measured in all solutions after $0.5,24$ and $48 \mathrm{~h}$ incubation in the light. Temperature was maintained at $30^{\circ} \mathrm{C}$ within a MINITRON incubator (INFORS) with shaking at $100 \mathrm{rpm}$. For residual ${ }^{90} \mathrm{Sr}$ quantification, $1 \mathrm{~mL}$ of cell suspension was centrifuged at $8500 \mathrm{~g}$ for $10 \mathrm{~min}$ and the supernatant was filtered on a $0.22 \mu \mathrm{m}$ PVDF syringe filter. The volume of the filtered supernatant was measured as $930 \pm 2 \mu \mathrm{L}$. Two milliliters of scintillating solution (Ultima Gold ${ }^{\mathrm{TM}}$, PerkinElmer) were added to the filtrates before counting on a Tri-Carb ${ }^{\circledR} 3100 \mathrm{TR}$ low activity liquid scintillation analyzer (PerkinElmer). For total ${ }^{90} \mathrm{Sr}$ content quantification, $930 \mu \mathrm{L}$ of cell suspension were mixed with $2 \mathrm{~mL}$ scintillating solution and counted. ${ }^{90} \mathrm{Sr}$ standard solutions were prepared with the ${ }^{90} \mathrm{Sr}$ stock solution (LEA, Pierrelatte, France), diluted in BG-11 medium and counted as described for the other samples. The counts per second (CPS) values were corrected from the background activity, measured with a control made of $930 \mu \mathrm{L}$ of BG-11 medium and 2 $\mathrm{mL}$ scintillation solution. The concentration of ${ }^{90} \mathrm{Sr}\left(\mathrm{Bq} \mathrm{L}^{-1}\right)$ in the samples was derived from the standards.

\section{Calculation of bioaccumulation of ${ }^{90} \mathrm{Sr}$ and ${ }^{226} \mathrm{Ra}$}

229 The mass of ${ }^{90} \mathrm{Sr}$ and ${ }^{226} \mathrm{Ra}$ accumulated by the cells at a time $t$ and normalized by the cell 230 mass was determined as follows: 
For ${ }^{226} \mathrm{Ra}$ :

233 and for ${ }^{90} \mathrm{Sr}$ :

where $\mathrm{X}$ denotes radionuclide activity $\left(\mathrm{Bq} \mathrm{L}^{-1}\right), \alpha$ is the factor to convert activity of a radionuclide to mass units and $t$ is the sampling time. The value of $\alpha$ for ${ }^{226} \mathrm{Ra}$ and ${ }^{90} \mathrm{Sr}$ is equal to $1.2 \times 10^{-13}\left(\mathrm{~mol} \mathrm{~Bq}^{-1}\right)$ and $2.2 \times 10^{-15}\left(\mathrm{~mol} \mathrm{~Bq}^{-1}\right)$.

\section{RESULTS AND DISCUSSION}

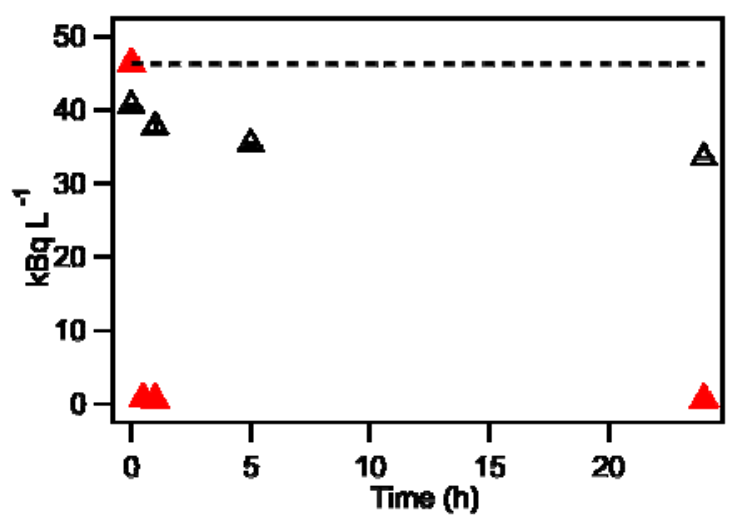

Figure 1: Time evolution of residual ${ }^{90} \mathrm{Sr}$ activity in the solution during exposure of $G$. lithophora cells to $8.8 \times 10^{-11} \mathrm{M}{ }^{90} \mathrm{Sr}(\Delta)$ and in the abiotic control $(\Delta)$, both in BG-11. The dash lines denote the initial total activity of ${ }^{90} \mathrm{Sr}$ added to the cultures. When not visible, error bars are smaller than the symbols.

\section{Kinetics of ${ }^{90} \mathrm{Sr}$ uptake by G. lithophora}

In order to demonstrate the uptake of radionuclides by G. lithophora, we first

242 monitored uptake of ${ }^{90} \mathrm{Sr}$ at high cell density to avoid any potential toxic effects on its 243 growth by ${ }^{90} \mathrm{Sr}$. The residual ${ }^{90} \mathrm{Sr}$ activity in solution during exposure of G. lithophora cells 
to $8.8 \times 10^{-11} \mathrm{M}{ }^{90} \mathrm{Sr}$ is shown in Figure $1 .{ }^{90} \mathrm{Sr}$ was rapidly removed from the solution in the presence of G. lithophora: the residual ${ }^{90} \mathrm{Sr}$ activity in the solution decreased from $46.243 \pm$ $0.604 \mathrm{kBq} \mathrm{L}^{-1}$ to $0.753 \pm 0.129 \mathrm{kBq} \mathrm{L}^{-1}$ within $1 \mathrm{~h}$, corresponding to the sequestration of 98 $\%$ of the radionuclide by the cells. The presence of divalent ions (e.g. $\mathrm{Ca}^{2+}, \mathrm{Mg}^{2+}$ ) in solution did not inhibit ${ }^{90} \mathrm{Sr}$ uptake by G. lithophora cells, consistent with results obtained with stable $\mathrm{Sr}^{33}$. Following the observed rapid decline of the residual ${ }^{90} \mathrm{Sr}$ activity in the solution, the rate of ${ }^{90} \mathrm{Sr}$ uptake by G. lithophora decreased. At the end of incubation $(48 \mathrm{~h})$, 251 the residual ${ }^{90} \mathrm{Sr}$ activity reached $0.608 \mathrm{kBq} \mathrm{L}^{-1}$, corresponding to $99 \%$ of radionuclide 252 removal by the cells. Here, removal of ${ }^{90} \mathrm{Sr}$ by G. lithophora occurred from solutions 253 containing a high concentration of $\mathrm{Ca}$, with an initial $\mathrm{Ca} /{ }^{90} \mathrm{Sr}$ molar ratio of $2.7 \times 10^{6}$. Thus $G$.

254 lithophora can efficiently sequester ${ }^{90} \mathrm{Sr}$ at trace concentrations despite the presence of a 255 large excess of competing cations. Within abiotic controls, only $12 \%$ of ${ }^{90} \mathrm{Sr}$ was removed 256 from solution within 5 hours, and ${ }^{90} \mathrm{Sr}$ activity remained constant thereafter for the duration 257 of the experiment. 

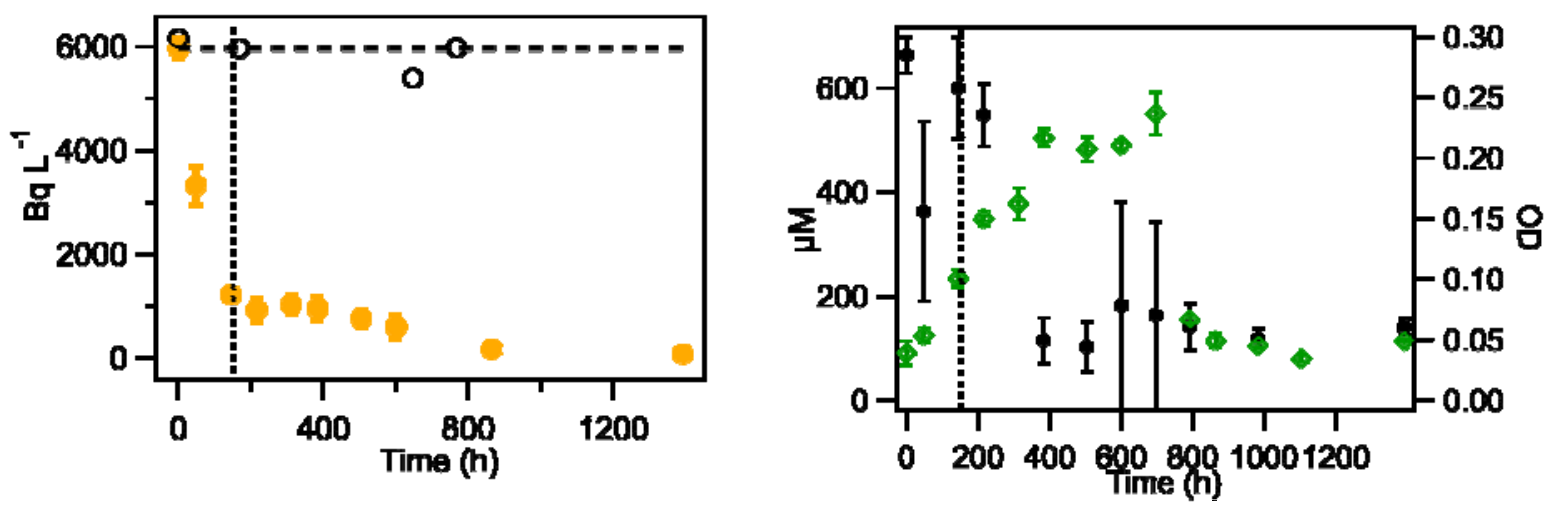

Figure 2: (Left) Time evolution of residual ${ }^{226} \mathrm{Ra}$ activity in the solution during growth of G. lithophora with $8 \times 10^{-10} \mathrm{M}^{226} \mathrm{Ra}(0)$ and in abiotic control (o), both in BG-11. Error bars denote the standard deviations of triplicate measurements. The horizontal dash line indicates the activity of ${ }^{226} \mathrm{Ra}$ added to the BG-11 media used for growing G. lithophora. (Right) Time evolution of dissolved $\mathrm{Ca}^{2+}(\mathbf{Q})$ concentration and OD $(\widehat{)})$ of cell suspension during growth of G. lithophora in BG-11 amended with 8 x $10^{-10} \mathrm{M}^{226} \mathrm{Ra}$. When not visible, error bars are smaller than the symbols, except for the abiotic control, for which triplicate measurements were not performed. The vertical dash line indicates the beginning of the second stage of ${ }^{226}$ Ra uptake.

stage of G. lithophora. For this purpose, we measured ${ }^{226} \mathrm{Ra}$ uptake upon the growth of $G$.

lithophora cells starting at a low cell density.

The uptake of ${ }^{226} \mathrm{Ra}$ by $\mathrm{G}$. lithophora was examined within low-cell density cultures

for reasons described above, and occurred in two stages (Figure 2, left). In the first stage,

${ }^{226} \mathrm{Ra}$ was rapidly removed from solution, with ${ }^{226} \mathrm{Ra}$ activity decreasing from $5964 \pm 192.2$

$267 \mathrm{~Bq} \mathrm{~L}^{-1}$ to $1227.68 \pm 85.5 \mathrm{~Bq} \mathrm{~L}^{-1}$ in $144 \mathrm{~h}$. This removal was accompanied by a slight decrease in dissolved $\mathrm{Ca}^{2+}$ (Figure 2, right). In the second stage, the rate of removal of ${ }^{226} \mathrm{Ra}$ from the solution slowed down and residual ${ }^{226} \mathrm{Ra}$ activity in the solution further decreased to $82 \mathrm{~Bq} \mathrm{~L}^{-1}$ in $1392 \mathrm{~h}$. The initial period of this $2^{\text {nd }}$ stage was marked with an appreciable 
271 decrease in dissolved $\mathrm{Ca}^{2+}$ in comparison to the $1^{\text {st }}$ stage. After this marked decrease,

272 dissolved $\mathrm{Ca}^{2+}$ remained constant.

273 G. lithophora showed active growth during $792 \mathrm{~h}$ as shown by OD measurements 274 (Figure 2, right). During this period, OD reached a value of $\sim 0.3$, then a sharp decline in OD 275 was observed. Concomitantly, extracellular $\mathrm{Ca}^{2+}$ concentration remained constant and ${ }^{226} \mathrm{Ra}$ 276 in the soluble fraction decreased. The cause of this sharp decline in OD is unclear, but 277 possible reasons are presented later in the discussion (See Maximum uptake of ${ }^{226} \mathrm{Ra}$ and $278{ }^{90} \mathrm{Sr}$ in G. lithophora). At the end of incubation $(1392 \mathrm{~h}), 99 \pm 5 \%$ of initial ${ }^{226} \mathrm{Ra}$ was 279 removed from the solution.

280 Retention mechanisms of ${ }^{226} \mathrm{Ra}$ and ${ }^{90} \mathrm{Sr}$ in G. lithophora 
283 other mechanisms, we compared uptake of ${ }^{226} \mathrm{Ra}$ and ${ }^{90} \mathrm{Sr}$ between living and dead cells of $G$.

284 lithophora. The average uptake of ${ }^{226} \mathrm{Ra}$ in inactivated cell control, composed of dead cells of $G$.

285 lithophora, was equal to $0.8 \pm 0.1 \mu \mathrm{g}$ (g of dry mass) ${ }^{-1}$; in contrast the average ${ }^{226} \mathrm{Ra}$ uptake by 286 active G. lithophora cells reached $3.9 \pm 0.9 \mu \mathrm{g}\left(\mathrm{g}\right.$ of dry mass) ${ }^{-1}$ (Table 1Table 1$)$. Likewise, the
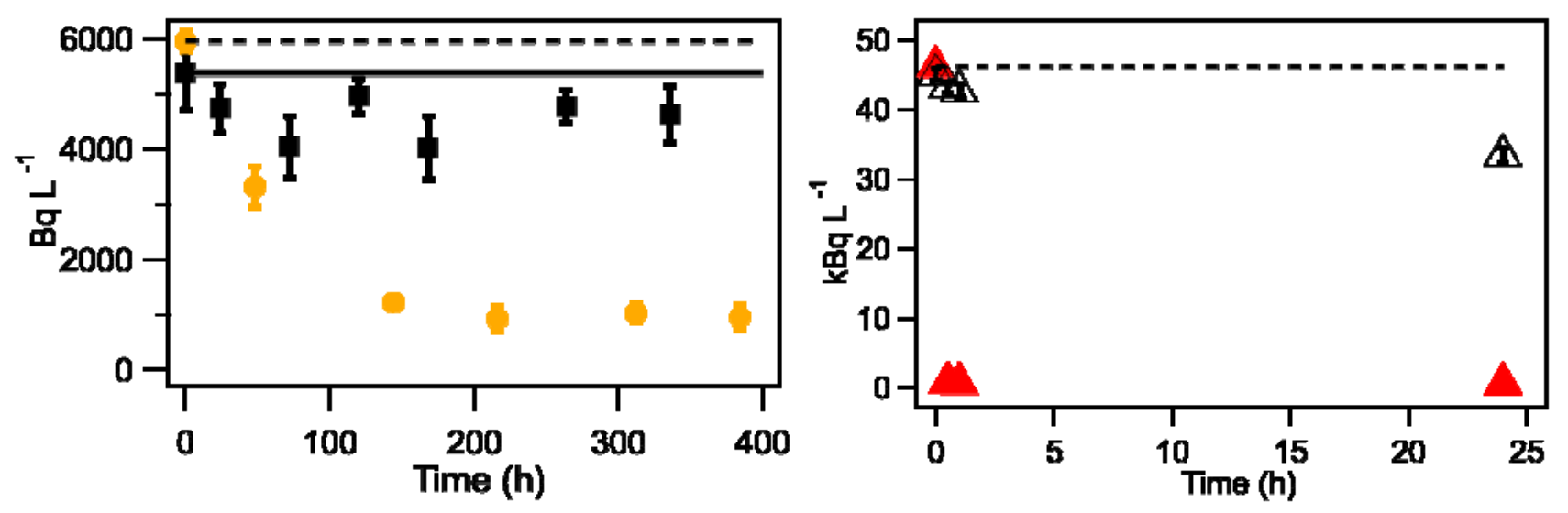

Figure 3: (Left) Time evolution of residual ${ }^{226} \mathrm{Ra}$ activity in the solution during growth of G. lithophora $(\bullet)$ and Synechocystis PCC 6803 (๘) in BG-11. (Right) Time evolution of residual ${ }^{90} \mathrm{Sr}$ activity in high cell density suspensions $(\mathrm{OD}=0.5)$ of $G$. lithophora $(\Delta)$ and Synechocystis PCC $6803(\Delta)$, both suspended in BG-11. The activity of ${ }^{226}$ Ra added to BG-11 media is shown as dash line for G. lithophora cultures, and solid line for Synechocystis cultures. The activity of ${ }^{90} \mathrm{Sr}$ added to BG-11 media is shown as dash line for G. lithophora and Synechocystis cultures. Error bar shows $\pm \sigma$.

average uptake of ${ }^{90} \mathrm{Sr}$ by dead G. lithophora cells was equal to $8.87 \pm 0.2 \mathrm{ng}$ (g of dry mass) $)^{-1}$;

288 in contrast the average ${ }^{90} \mathrm{Sr}$ uptake rate by active cells of $\mathrm{G}$. lithophora measured $47.97 \pm 1.5 \mathrm{ng}$

289 (g of dry mass $)^{-1}$ (Table 1$)$. Second, the relationship between biomineralization and

290 sequestration of ${ }^{226} \mathrm{Ra}$ and ${ }^{90} \mathrm{Sr}$ was tested by comparing uptake of ${ }^{226} \mathrm{Ra}$ and ${ }^{90} \mathrm{Sr}$ by living cells

291 of the non-biomineralizing Synechocystis and living cells of G. lithophora. The OD of

292 Synechocystis during the incubation period is shown in Figure S1. Living cells of the non-

293 biomineralizing Synechocystis retained $14 \pm 2 \%$ of ${ }^{226} \mathrm{Ra}$ in $336 \mathrm{~h}$, while G. lithophora retained 
$83 \pm 14 \%$ of ${ }^{226} \mathrm{Ra}$ over the same duration (Figure 3). Similarly, incubation over $24 \mathrm{~h}$ of the nonbiomineralizing Synechocystis at relatively high cell density $(\mathrm{OD}=0.5)$ retained $26 \pm 1 \%$ of ${ }^{90} \mathrm{Sr}$, while G. lithophora retained $99.5 \pm 10 \%$ of the initial ${ }^{90} \mathrm{Sr}$ (Figure 3). While there could be differences in the cell surface composition between both strains, we argue that these differences are likely not substantial enough to induce 6 times more ${ }^{226} \mathrm{Ra}$ and 4 times more ${ }^{90} \mathrm{Sr}$ retention in G. lithophora than in Synechocystis PCC 6803. Altogether, these results suggest specific cellular processes are responsible for ${ }^{226} \mathrm{Ra}$ and ${ }^{90} \mathrm{Sr}$ retention by G. lithophora.

Table 1: Comparison of ${ }^{226} \mathrm{Ra}$ and ${ }^{90} \mathrm{Sr}$ uptake per unit biomass in different incubations

\begin{tabular}{|c|c|c|}
\hline Sample ID & $\begin{array}{c}{ }^{226} \text { Ra Retained* } \\
\mu g \text { (g of dry mass) }^{-1}\end{array}$ & $\begin{array}{c}{ }^{90} \mathrm{Sr} \text { retained }{ }^{* *} \\
\text { ng }(\mathrm{g} \text { of dry mass) })^{-1}\end{array}$ \\
\hline Live G. lithophora cells & $3.9 \pm 0.9$ & $47.9 \pm 1.5$ \\
\hline Dead G. lithophora cells & $0.8 \pm 0.1$ & $8.87 \pm 0.2$ \\
\hline
\end{tabular}

Microbial processes of ${ }^{226} \mathrm{Ra}$ and ${ }^{90} \mathrm{Sr}$ sequestration can broadly be categorized into 308 three groups: extracellular biomineralization, adsorption, and intracellular 309 biomineralization $^{24}$. Microbially induced extracellular biomineralization requires localized 310 supersaturation of the solution with respect to Ca-carbonate phases. This results in 311 precipitation of carbonate solids and ${ }^{226} \mathrm{Ra}$ and ${ }^{90} \mathrm{Sr}$ may co-precipitate within these 
extracellular solids and be removed from the solution. Using Visual Minteq ${ }^{38}$, we calculated the saturation state of the solution with respect to Ca-carbonate phases to verify if this mechanism was operational. Visual MINTEQ predicts that the experimental culture media amended with ${ }^{226} \mathrm{Ra}$ and ${ }^{90} \mathrm{Sr}$ remained undersaturated with respect to Ca-carbonate phase(s) (Figure S2- S3). Moreover, the state of solution undersaturation with respect to Cacarbonate solids is consistent with the observation that dissolved ${ }^{226} \mathrm{Ra}$ and ${ }^{90} \mathrm{Sr}$ activity remained close to their initial activities in the abiotic control (Figure 1-2). Therefore, extracellular precipitates of Ca-carbonate phases could not be a plausible sink of ${ }^{226} \mathrm{Ra}$ and ${ }^{90} \mathrm{Sr}$ in our study.

One of the physicochemical processes that has been used widely for sequestering low levels of contaminants from aqueous solutions is adsorption. Here, based on Figure 3 and Table 1, adsorption of ${ }^{226} \mathrm{Ra}$ and ${ }^{90} \mathrm{Sr}$ at walls of culture flasks, at the cell surface and dead $G$. lithophora biomass, removed $22 \%{ }^{226} \mathrm{Ra}$ and $18 \%{ }^{90} \mathrm{Sr}$ from solution, suggesting that adsorption alone cannot reproduce the degree of ${ }^{226} \mathrm{Ra}$ and ${ }^{90} \mathrm{Sr}$ retained by G. lithophora. The dissolved concentration of $\mathrm{Ca}^{2+}$ in ${ }^{226} \mathrm{Ra}$ uptake experiments by active cells of $\mathrm{G}$. lithophora was higher than the concentration of dissolved $\mathrm{Ca}^{2+}$ in the inactivated cell control and the Synechocystis cultures. Because of competing effects for adsorption between Ca and $\mathrm{Ra}$, this implies that the degree of ${ }^{226} \mathrm{Ra}$ adsorption measured in the inactivated cell and by Synechocystis controls was relatively overestimated compared to that in the presence of active G. lithophora cells will likely be less in presence of excess $\mathrm{Ca}^{2+}$ furnished in ${ }^{226} \mathrm{Ra}$ uptake experiments (Figure 2). Moreover, the cell normalized rate of uptake measured for

${ }^{90} \mathrm{Sr}$ is consistent with those measured by Cam et al. for stable $\mathrm{Sr}$ isotope and shown to be associated with intracellular uptake rather than adsorption ${ }^{33}$. These observations taken 
altogether suggests that mechanism(s) other than adsorption are involved in ${ }^{226} \mathrm{Ra}$ and ${ }^{90} \mathrm{Sr}$ uptake in G. lithophora.

Previously, TEM analyses of G. lithophora cells cultured in BG-11, amended with high initial concentrations of stable $\mathrm{Ba}$ and $\mathrm{Sr}$ isotopes showed that most of the $\mathrm{Sr}$ and $\mathrm{Ba}$ were sequestered within intracellular carbonates and to a lesser extent in intracellular polyphosphates. Unfortunately, TEM analysis was not possible here to assess ${ }^{226} \mathrm{Ra}$ and ${ }^{90} \mathrm{Sr}$ distribution within the cell because their concentrations were below the detection limits of $\mathrm{EDXS}^{39}$. Nevertheless, considering ${ }^{226} \mathrm{Ra}$ and ${ }^{90} \mathrm{Sr}$ chemical affinities and similarity to $\mathrm{Ca}$ and $\mathrm{Ba}$, we propose that incorporation of ${ }^{226} \mathrm{Ra}$ and ${ }^{90} \mathrm{Sr}$ into intracellular carbonate (and polyphosphate) inclusions is likely the primary mechanisms for their sequestration in $G$. lithophora. It remains a mystery why G. lithophora would sequester radiotoxic ${ }^{226} \mathrm{Ra}$ and ${ }^{90} \mathrm{Sr}$ elements within the cell. Unlike $\mathrm{Ca}$, which is essential as a co-factor for cyanobacteria in the photosystem II complex ${ }^{40}$, there is no documented biological function of ${ }^{226} \mathrm{Ra},{ }^{90} \mathrm{Sr}$ or Ba. Some studies have argued that trace amounts of non-essential elements can be assimilated together with their corresponding essential analogues ${ }^{24}$. In fact, non-selective transport of $\mathrm{Sr}^{2+}$ through cation channels have already been acknowledged by other studies ${ }^{41}$. Hence, ${ }^{226} \mathrm{Ra}$ and ${ }^{90} \mathrm{Sr}$ could be "mistaken" for its chemical analog $\mathrm{Ca}$, an essential element, thereby resulting in their favorable uptake in G. lithophora. Alternatively, while this is not ascertained by the present experiments, selective uptake of ${ }^{226} \mathrm{Ra}$ and ${ }^{90} \mathrm{Sr}$ by $G$. lithophora should may also be considered because of two reasons: (1) Cam et al. showed that G. lithophora selectively uptakes stable $\mathrm{Sr}$ over $\mathrm{Ca}^{33}$; (2) Uptake of ${ }^{226} \mathrm{Ra}$ and ${ }^{90} \mathrm{Sr}$ by $G$. lithophora was not inhibited by $\mathrm{Ca}^{2+}$, present at approximately 6 orders of magnitude higher concentration than ${ }^{226} \mathrm{Ra}$ and ${ }^{90} \mathrm{Sr}$. These observations favor involvement of another 
biochemical process at play in G. lithophora. Typically, ion selectivity between similar ions such $\mathrm{Sr}, \mathrm{Ra}, \mathrm{Ba}, \mathrm{Ca}$ requires an ion transport pathway to have some specific binding sites over at least part of its length. Future studies characterizing the affinity and specificity of various transporters involved in uptake of AEE in G. lithophora along with measurement of ${ }^{90} \mathrm{Sr}$ and ${ }^{226} \mathrm{Ra}$ uptake by G. lithophora at varying $\mathrm{Ca}:{ }^{90} \mathrm{Sr} /{ }^{226} \mathrm{Ra}$ ratio may shed some light on molecular processes involved in uptake of ${ }^{90} \mathrm{Sr}$ and ${ }^{226} \mathrm{Ra}$ by G. lithophora.

\section{Maximum uptake of ${ }^{226} \mathrm{Ra}$ and ${ }^{90} \mathrm{Sr}$ by $\mathrm{G}$. lithophora}

Understanding the maximum uptake capacity of ${ }^{226} \mathrm{Ra}$ and ${ }^{90} \mathrm{Sr}$ by G. lithophora is an important criterion for its assessment as a potential bioremediation strategy. The maximum radionuclide uptake capacity by a microorganism is an elusive concept as a zero net uptake rate doesn't always signal maximum uptake capacity. For example, net uptake may appear to cease when the amount of radionuclide added to the solution is exhausted before the cells reach their maximum uptake capacity. In the case of ${ }^{226} \mathrm{Ra}$, the total ${ }^{226} \mathrm{Ra}$ accumulated in $G$. lithophora over the total duration of incubation equals to $133 \mathrm{kBq}$ (g of dry mass) $)^{-1}$ (Figure 2 and Table1). The OD decline after $792 \mathrm{~h}$ may possibly indicate cell lysis and/or cell aggregation, settling and/or attachment of cells to the flasks. Visual inspection of the cultures after $792 \mathrm{~h}$ did reveal some aggregation and settling of the cells (data no shown). The decrease in the uptake of ${ }^{226} \mathrm{Ra}$ during the $2^{\text {nd }}$ stage may signal that the cells have reached maximum ${ }^{226} \mathrm{Ra}$ uptake capacity. To test whether this is the case, cultures of $G$. lithophora were grown in BG-11 containing ${ }^{226} \mathrm{Ra}$ at a concentration 25 times higher than the experiment here. The high ${ }^{226} \mathrm{Ra}$ concentration experiments showed that over 30 days $70 \%$ of ${ }^{226} \mathrm{Ra}$ was removed and $962 \mathrm{kBq}$ (g of biomass) ${ }^{-1}{ }^{226} \mathrm{Ra}$ sequestered by G. lithophora (Figure S4). This implies that the decrease in ${ }^{226} \mathrm{Ra}$ uptake rate during $2^{\text {nd }}$ stage is not 
because cells reached maximum uptake capacity but for some other reasons yet to be discovered. Similar to ${ }^{226} \mathrm{Ra}$, total ${ }^{90} \mathrm{Sr}$ accumulated by G. lithophora in $24 \mathrm{~h}$ was equal to $250 \mathrm{kBq}$ (g of biomass) $)^{-1}$ (Figure 1 and Table1). To test whether this amount of ${ }^{90} \mathrm{Sr}$ sequestered was equal to maximum uptake capacity, culture of G. lithophora at high cell density were successively spiked with ${ }^{90} \mathrm{Sr}$ and uptake of ${ }^{90} \mathrm{Sr}$ measured in the supernatant. The multiple spike experiments showed that $924 \mathrm{kBq}$ (g of biomass) ${ }^{-1}$ was incorporated within G. lithophora over $24 \mathrm{hr}$ (Figure S5). After $24 \mathrm{~h}$, no further ${ }^{90} \mathrm{Sr}$ accumulation was measured as the cells exhausted the amount of ${ }^{90} \mathrm{Sr}$ provided. Together, these observations suggest that in the present study, measured ${ }^{226} \mathrm{Ra}$ and ${ }^{90} \mathrm{Sr}$ accumulation by G. lithophora is a lower estimate of its maximum uptake capacity.

\section{Environmental Implications and Bioremediation}

Both uptake capacity and selectivity play an important feature for assessment of an organism's effectiveness for ${ }^{90} \mathrm{Sr}$ and ${ }^{226} \mathrm{Ra}$ remediation. Tables 2 and 3 compare ${ }^{90} \mathrm{Sr}$ and ${ }^{226} \mathrm{Ra}$ uptake capacity of $\mathrm{G}$. lithophora with other organisms known to uptake ${ }^{90} \mathrm{Sr}$ or ${ }^{226} \mathrm{Ra}$. For the screened bioremediation candidates, uptake capacities of ${ }^{90} \mathrm{Sr}$ and ${ }^{226} \mathrm{Ra}$ are reported assuming ideal conditions, i.e. in absence of $\mathrm{Ca}$ and other divalent ions. Such conditions are not representative of environments contaminated with ${ }^{90} \mathrm{Sr}$ and ${ }^{226} \mathrm{Ra}$, which contain excess $\mathrm{Ca}$ and/or other divalent ions. Presence of $\mathrm{Ca}$ and other divalent ions in the solution may compromise the uptake of ${ }^{226} \mathrm{Ra}$ and ${ }^{90} \mathrm{Sr}$. For example, $40 \%$ of ${ }^{90} \mathrm{Sr}$ was removed by Vetiveria zizanoids from solution containing $\mathrm{Ca} /{ }^{90} \mathrm{Sr}$ molar ratio of $3.6 \times 10^{6}$, while $94 \%$ removal was achieved in absence of $\mathrm{Ca}^{42}$. In another example, Calotropis gigantea exhibited high accumulation of ${ }^{90} \mathrm{Sr}\left(104 \mathrm{ng} \mathrm{g}^{-1}\right)$ but from a solution containing only ${ }^{90} \mathrm{Sr}^{43}$. 
Whether the high ${ }^{90} \mathrm{Sr}$ removal efficiency of $C$. gigantea is maintained within an environmentally relevant matrix remains unknown. In the case of ${ }^{226} \mathrm{Ra}$, the uptake exhibited by dead biomass was achieved under conditions where ${ }^{226} \mathrm{Ra}$ was the only AEE present and therefore unlikely to be replicated in the environment to the same extent. Therefore, the current bioremediation strategies listed in Table 2-3 are inadequate in efficiently achieving selective removal of ${ }^{226} \mathrm{Ra}$ and ${ }^{90} \mathrm{Sr}$ in the presence of Ca. uptake by organisms.

\begin{tabular}{|c|c|}
\hline & Radium Uptake \\
\hline Dead Biomass & $\left(\mu \mathrm{g} \mathrm{g}^{-1}\right)$ \\
\hline P. fluorescens ${ }^{44}$ & 0.02 \\
\hline Streptomycene nives ${ }^{44}$ & 0.58 \\
\hline Activated sludge ${ }^{44}$ & 0.075 \\
\hline Activated sludge ${ }^{45}$ & 0.04 \\
\hline$N$. carneum ${ }^{25}$ & 1.3 \\
\hline$N$. insulare $^{25}$ & 1.2 \\
\hline O. geminata ${ }^{25}$ & 1.35 \\
\hline S. laxissima ${ }^{25}$ & 1.3 \\
\hline Serratia sp. ZF03 $3^{45}$ & 1.03 \\
\hline P. chrysogenum ${ }^{46}$ & 0.076 \\
\hline G. emersonii ${ }^{47}$ & 1.86 \\
\hline \multicolumn{2}{|l|}{ Live Biomass } \\
\hline D. linearis ${ }^{48}$ & 4.5 \\
\hline G. lithophora (this study)* & 26.1 \\
\hline
\end{tabular}

* based on G. lithophora grown in elevated ${ }^{226}$ Ra activity in a preliminary experiment (Figure S4)

On the other hand, G. lithophora exhibits highest uptake of ${ }^{90} \mathrm{Sr}$ and ${ }^{226} \mathrm{Ra}$ among all

413 the active and dead microorganisms. Since OD values in experiments using ${ }^{90} \mathrm{Sr}$ were 414 measured under the same conditions and setup as in Cam et $\mathrm{al}^{36}$, their conversion to cell numbers and cell mass are expected to be correct. Alternatively, we note that quantity of ${ }^{226} \mathrm{Ra}$ sequestered per unit biomass of G. lithophora cells might be approximate estimations 
417 only because presence of ${ }^{226} \mathrm{Ra}$ during growth of $G$. lithophora may induce physiological 418 changes and alter the previously reported relationship between OD, cell density, and cell $419 \mathrm{mass}^{36}$.Unlike previously reported uptake studies, G. lithophora uptakes ${ }^{90} \mathrm{Sr}$ and ${ }^{226} \mathrm{Ra}$ in 420 presence of excess $\mathrm{Ca}$ - initial molar ratio of $\mathrm{Ca} /{ }^{90} \mathrm{Sr}$ and $\mathrm{Ca} /{ }^{226} \mathrm{Ra}$ of the cultures equal $2.3 \times 10^{6}$ and $1.2 \times 10^{6}$ respectively. Interestingly, ${ }^{226} \mathrm{Ra}$ accumulation by G. lithophora's overwhelmingly exceeds ${ }^{226} \mathrm{Ra}$ uptake capacity of Dicranopteris linearis, identified as a ${ }^{226} \mathrm{Ra}$ hyper-accumulator ${ }^{48}$. The remarkable ability of $G$. lithophora to retain high activities 424 of ${ }^{226} \mathrm{Ra}$ and ${ }^{90} \mathrm{Sr}$ in comparison with other organisms makes it an attractive candidate for 425 bioremediation applications in decontamination of low salinity radioactive wastewater 426 streams. Such a strategy could be envisioned as an ex-situ treatment, integrated (e.g. as a 427 bioreactor) within an existing wastewater treatment plant. Compared to G. lithophora, other ${ }^{90} \mathrm{Sr} /{ }^{226} \mathrm{Ra}$ bioremediation candidates are mostly plants (Table2-3). There are practical considerations of using cyanobacterium G. lithophora vs. plants for bioremediation, such as harvesting of biomass, growth times, duration of decontamination and treatment of radioactive biomass. A complete development of G. lithophora based bioremediation would require determining these aspects in future studies.

Table 3: Comparison of Sr uptake in G. lithophora with previously reported experimental data on ${ }^{90} \mathrm{Sr}$ uptake by

\begin{tabular}{|c|c|c|}
\hline & Uptake capacity $\left(\mathrm{ng} \mathrm{g}^{-1}\right)$ & \% removal \\
\hline \multicolumn{3}{|l|}{ Organism } \\
\hline V. zizanoides $(0 \mathrm{mM} \mathrm{Ca})^{42}$ & - & $94 \%$ \\
\hline V. zizanoides $(40 \mathrm{mM} \mathrm{Ca})^{42}$ & - & $40 \%$ \\
\hline Paspalum notatum ${ }^{49 * *}$ & 0.14 & $20 \%$ \\
\hline Sorghum halense $49 * *$ & 0.14 & $32 \%$ \\
\hline Panicum virginatum ${ }^{49 * *}$ & 0.15 & $23 \%$ \\
\hline Amaranthus retoflexus ${ }^{50}$ & 0.000077 & $5 \%$ \\
\hline Calotropis gigantea $^{43 *}$ & 103.37 & $97 \%$ \\
\hline G. lithophora (this study) ${ }^{+}$ & 177 & $99 \%$ \\
\hline
\end{tabular}

* Uptake achieved in $168 \mathrm{~h}$

** Concentration in plant tissue after 8 weeks of harvest

${ }^{+}$Based on multi-spike experiment (Figure S5) 

microorganism to survive in the presence of ionizing radiation. The intracellular uptake of radiotoxic ${ }^{226} \mathrm{Ra}$ and ${ }^{90} \mathrm{Sr}$ could potentially result in oxidative damage in DNA, proteins and lipids due to the generation of reactive oxygen species. Cyanobacteria have been detected in radioactive areas surrounding Chernobyl nuclear reactor ${ }^{51}$, uranium mining operations ${ }^{52}$ and in vicinity of hydrothermal spring caves $^{53}$, suggesting that they may have some degree of resistance to ionizing radiation. However, little is known about G. lithophora's radiotolerance and response to oxidative stress and future experiments characterizing the 443 viability of $G$. lithophora cells when exposed to elevated radiation could provide some 444 insights in this regard.

G. lithophora sequesters ${ }^{226} \mathrm{Ra}$ and ${ }^{90} \mathrm{Sr}$ within intracellular ACC inclusions at very low extracellular $\mathrm{Ra} / \mathrm{Ca}$ concentration ratios, offering a unique solution to the general problem of remediating ${ }^{226} \mathrm{Ra}$ and ${ }^{90} \mathrm{Sr}$ in aqueous environments with naturally high $\mathrm{Ca}$ concentrations. Further studies investigating the stability of intracellular inclusions in environmentally relevant matrices and optimization of various process parameters such as maximum ${ }^{226} \mathrm{Ra}$ and ${ }^{90} \mathrm{Sr}$ uptake capacity, and tolerance to other metalloids present in the waste streams will be needed to ensure successful development of G. lithophora based bioremediation approach for ${ }^{90} \mathrm{Sr}$ and ${ }^{226} \mathrm{Ra}$.

\section{ASSOCIATED CONTENT}

This manuscript is accompanied by Supporting Information. An extra document contains 5

455 figures. Data on OD of cultures in absence of radionuclide, saturation indices of $\mathrm{Ca}$ and $\mathrm{Sr}$ 456 solids in the solution, ${ }^{226} \mathrm{Ra}$ uptake by G. lithophora from BG-11 containing $210 \mathrm{kBq} \mathrm{L}{ }^{-1}$ 457 ${ }^{226} \mathrm{Ra}$, and data on uptake of ${ }^{90} \mathrm{Sr}$ by G. lithophora during successive spike experiment. 


\section{ACKNOWLEDGMENTS}

We would like to thank Timothy McClure (MIT) for his assistance with ICP-OES, Ryan Samz and Mitchell S Galanek, MIT Environmental Health and Safety, for supplying

${ }^{226} \mathrm{Ra}$ stock solutions, radiation protection equipment and safety expertise. We thank Fériel Skouri-Panet and Margot Coutaud (IMPMC) for assistance in the Sr experiments. The authors declare no competing financial interest.

\section{REFERENCE}

(1) Hutchins, D.; Mulholland, M.; Fu, F. Nutrient Cycles and Marine Microbes in a CO2Enriched Ocean. Oceanography 2009, 22 (4), 128-145.

(2) Riding, R. Cyanobacterial Calcification, Carbon Dioxide Concentrating Mechanisms, and Proterozoic-Cambrian Changes in Atmospheric Composition. Geobiology 2006, 4 (4), 299-316.

(3) Benzerara, K.; Skouri-Panet, F.; Li, J.; Ferard, C.; Gugger, M.; Laurent, T.; Couradeau, E.; Ragon, M.; Cosmidis, J.; Menguy, N.; Margaret-Oliver, I.; Tavera, R.; Lopez-Garcia, P.; Moreira, D. Intracellular Ca-Carbonate Biomineralization Is Widespread in Cyanobacteria. Proc. Natl. Acad. Sci. 2014, 111 (30).

(4) Couradeau, E.; Benzerara, K.; Gérard, E.; Moreira, D.; Bernard, S.; Brown, G. E. J.; López-García, P. An Early-Branching Microbialite Cyanobacterium Forms Intracellular Carbonates. Science. 2012, 336, 459-462.

(5) De Wever, A.; Benzerara, K.; Gugger, M.; Coutaud, M.; Caumes, G.; Poinsot, M.; Skouri, F.; Thierry, P.; Elodie, L. Evidence of High Ca Uptake by Cyanobacteria Forming Intracellular CaCO 3 and Impact on Their Growth. Geobiology 2019, 1-15.

(6) Li, J.; Margaret Oliver, I.; Cam, N.; Boudier, T.; Blondeau, M.; Leroy, E.; Cosmidis, 
J.; Skouri-Panet, F.; Guigner, J.-M.; Férard, C.; Poinsot, M.; Moreira, D.; LopezGarcia, P.; Cassier-Chauvat, C.; Chauvat, F.; Benzerara, K. Biomineralization Patterns of Intracellular Carbonatogenesis in Cyanobacteria: Molecular Hypotheses. Minerals 2016, 6 (1), 10 .

(7) Szabo, Z.; dePaul, V. T.; Fischer, J. M.; Kraemer, T. F.; Jacobsen, E. Occurrence and Geochemistry of Radium in Water from Principal Drinking-Water Aquifer Systems of the United States. Appl. Geochemistry 2012, 27 (3), 729-752.

(8) United States Environmental Protection Agency. Radionuclides Rule _ Drinking Water Requirements for States and Public Water Systems _ US EPA.

(9) International Atomic Energy Agency (IAEA). The Environmental Behaviour of Radium: Revised Edition. Tech. Reports Ser. No. 476 2014, No. 476, 44-51.

(10) United States Nuclear Regulatory Commission. NRC: 10 CFR Part 20 - Appendix B Radionuclide Table - Cesium-137. 2017.

(11) Warner, N. R.; Cidney, C. A.; Jackson, R. B.; Vengosh, A. Impacts of Shale Gas Wastewater Disposal on Water Quality in Western PA. Environ. Sci. Technol. 2013, $1-14$.

(12) Chellam, S.; Clifford, D. A. Physical-Chemical Treatment of Groundwater Contaminated by Leachate from Surface Disposal of Uranium Tailings. J. Environ. Eng. 2002, 128 (10), 942-952.

(13) Casacuberta, N.; Masqué, P.; Garcia-Orellana, J.; Garcia-Tenorio, R.; Buesseler, K. O. $90 \mathrm{Sr}$ and $89 \mathrm{Sr}$ in Seawater off Japan as a Consequence of the Fukushima Dai-Ichi Nuclear Accident. Biogeosciences 2013, 10 (6), 3649-3659.

(14) Vakulovsky, S. M.; Nikitin, A. I.; Chumichev, V. B.; Katrich, I. Y.; Voitsekhovich, O. A.; Medinets, V. I.; Pisarev, V. V.; Bovkum, L. A.; Khersonsky, E. S. Cesium-137 and Strontium-90 Contamination of Water Bodies in the Areas Affected by Releases from the Chernobyl Nuclear Power Plant Accident: An Overview. J. Environ. Radioact. 1994, 23 (2), 103-122.

(15) Povinec, P. P.; Hirose, K.; Aoyama, M. Radiostrontium in the Western North Pacific: 

(18), 10356-10363.

(16) Idaho National Engineering Laboratory, I. Selected Radionuclides Important to LowLevel Radioactive Waste Management. 1996, No. November, 1-413.

(17) Pagnanelli, F.; Papini, M. P.; Toro, L.; Trifoni, M.; Vegliò, F. Biosorption of Metal Ions on Arthrobacter Sp.: Biomass Characterization and Biosorption Modeling. Environ. Sci. Technol. 2000, 34 (13), 2773-2778.

(18) Volesky, B. Detoxification of Metal-Bearing Effluents: Biosorption for the next Century. Hydrometallurgy 2001, 59 (2-3), 203-216.

(19) Brower, J. B.; Ryan, R. L.; Pazirandeh, M. Comparison of Ion-Exchange Resins and Biosorbents for the Removal of Heavy Metals from Plating Factory Wastewater. 1997, 31 (10), 2910-2914.

(20) Lloyd, J. R.; Renshaw, J. C. Bioremediation of Radioactive Waste: RadionuclideMicrobe Interactions in Laboratory and Field-Scale Studies. Curr. Opin. Biotechnol. 2005, 16, 254-260.

(21) Gadd, G. M. Metals, Minerals and Microbes: Geomicrobiology and Bioremediation. Microbiology 2010, 156 (3), 609-643.

(22) Ruggiero, C. E.; Boukhalfa, H.; Forsythe, J. H.; Lack, J. G.; Hersman, L. E.; Neu, M. P. Actinide and Metal Toxicity to Prospective Bioremediation Bacteria. Environ. Microbiol. 2005, 7 (1), 88-97.

(23) Tsezos, M.; Keller, D. M. Adsorption of Radium-226 by Biological Origin Absorbents. Biotechnol. Bioeng. 1983, 25 (1), 201-215.

(24) Newsome, L.; Morris, K.; Lloyd, J. R. The Biogeochemistry and Bioremediation of Uranium and Other Priority Radionuclides. Chem. Geol. 2014, 363, 164-184.

(25) Pohl, P.; Schimmack, W. Adsorption of Radionuclides (134Cs, 85Sr, 226Ra, 241 Am) by Extracted Biomasses of Cyanobacteria (Nostoc Carneum, N. Insulare, Oscillatoria Geminata and Spirulina Laxis-Sima) and Phaeophyceae (Laminaria Digitata and L. 
Japonica; Waste Products from Alginat. J. Appl. Phycol. 2006, 18 (2), 135-143.

540

541

(26) Satvatmanesh, D.; Siavoshi, F.; Beitollahi, M. M.; Amidi, J.; Fallahian, N. Biosorption of 226Ra in High Level Natural Radiation Areas of Ramsar, Iran. J. Radioanal. Nucl. Chem. 2003, 258 (3), 483-486.

(27) Liu, M.; Dong, F.; Kang, W.; Sun, S.; Wei, H.; Zhang, W.; Nie, X.; Guo, Y.; Huang, T.; Liu, Y. Biosorption of Strontium from Simulated Nuclear Wastewater by Scenedesmus Spinosus under Culture Conditions: Adsorption and Bioaccumulation Processes and Models. Int. J. Environ. Res. Public Health 2014, 11 (6), 6099-6118.

(28) Fukuda, S. ya; Iwamoto, K.; Atsumi, M.; Yokoyama, A.; Nakayama, T.; Ishida, K. ichiro; Inouye, I.; Shiraiwa, Y. Global Searches for Microalgae and Aquatic Plants That Can Eliminate Radioactive Cesium, Iodine and Strontium from the RadioPolluted Aquatic Environment: A Bioremediation Strategy. J. Plant Res. 2014, 127 (1), 79-89.

(29) Krejci, M. R.; Finney, L.; Vogt, S.; Joester, D. Selective Sequestration of Strontium in Desmid Green Algae by Biogenic Co-Precipitation with Barite. ChemSusChem 2011, $4(4), 470-473$.

(30) Lee, S. Y.; Jung, K. H.; Lee, J. E.; Lee, K. A.; Lee, S. H.; Lee, J. Y.; Lee, J. K.; Jeong, J. T.; Lee, S. Y. Photosynthetic Biomineralization of Radioactive Sr via Microalgal CO2absorption. Bioresour. Technol. 2014, 172, 449-452.

(31) Achal, V.; Pan, X.; Zhang, D. Bioremediation of Strontium (Sr) Contaminated Aquifer Quartz Sand Based on Carbonate Precipitation Induced by Sr Resistant Halomonas Sp. Chemosphere 2012, 89 (6), 764-768.

(32) Lauchnor, E. G.; Schultz, L. N.; Bugni, S.; Mitchell, A. C.; Cunningham, A. B.; Gerlach, R. Bacterially Induced Calcium Carbonate Precipitation and Strontium Coprecipitation in a Porous Media Flow System. Environ. Sci. Technol. 2013, 47 (3), $1557-1564$.

(33) Cam, N.; Benzerara, K.; Georgelin, T.; Jaber, M.; Lambert, J. F.; Poinsot, M.; SkouriPanet, F.; Cordier, L. Selective Uptake of Alkaline Earth Metals by Cyanobacteria 
Forming Intracellular Carbonates. Environ. Sci. Technol. 2016, 50 (21), 1165411662.

(34) Bailey, S.; Grossman, A. Photoprotection in Cyanobacteria: Regulation of Light Harvesting. Photochem. Photobiol. 2008, 84 (6), 1410-1420.

(35) Ragon, M.; Benzerara, K.; Moreira, D.; Tavera, R.; Lopez-Garcia, P. 16S RDNABased Analysis Reveals Cosmopolitan Occurrence but Limited Diversity of Two Cyanobacterial Lineages with Contrasted Patterns of Intracellular Carbonate Mineralization. Front. Microbiol. 2014, 5, 1-11.

(36) Moreira, D.; Tavera, R.; Benzerara, K.; Skouri-Panet, F.; Couradeau, E.; Gérard, E.; Fonta, C. L.; Novelo, E.; Zivanovic, Y.; López-García, P. Description of Gloeomargarita Lithophora Gen. Nov., Sp. Nov., a Thylakoid-Bearing, BasalBranching Cyanobacterium with Intracellular Carbonates, and Proposal for Gloeomargaritales Ord. Nov. Int. J. Syst. Evol. Microbiol. 2017, 67 (3), 653-658.

(37) Stanier, R. Y.; Deruelles, J.; Rippka, R.; Herdman, M.; Waterbury, J. B. Generic Assignments, Strain Histories and Properties of Pure Cultures of Cyanobacteria. Microbiology 1979, 111 (1), 1-61.

(38) Gustafsson, J. P. Visual MINTEQ 3.0 User Guide. Dep.of L. Water Resour.eng 2012, $1-73$.

(39) Blondeau, M.; Benzerara, K.; Ferard, C.; Guigner, J. M.; Poinsot, M.; Coutaud, M.; Tharaud, M.; Cordier, L.; Skouri-Panet, F. Impact of the Cyanobacterium Gloeomargarita Lithophora on the Geochemical Cycles of Sr and Ba. Chem. Geol. 2018, 483, 88-97.

(40) Debus, R. J. The Manganese and Calcium Ions of Photosynthetic Oxygen Evolution. Biochem. Biophys. Acta 1992, 1102 (3), 269-352.

(41) Gupta, D. K.; Schulz, W.; Steinhauser, G.; Walther, C. Radiostrontium Transport in Plants and Phytoremediation. Environ. Sci. Pollut. Res. 2018, 25 (30), 29996-30008.

(42) Singh, S.; Eapen, S.; Thorat, V.; Kaushik, C. P.; Raj, K.; D'souza, S. Phytoremediation of 137 cesium and 90strontium from Solutions and Low-Level 
Nuclear Waste by Vetiveria Zizanoides. Exotoxicology Enviornmental Saf. 2008, 69, 306-311.

(43) Eapen, S.; Singh, S.; Thorat, V.; Kaushik, C. P.; Raj, K.; D’Souza, S. F. Phytoremediation of Radiostrontium ( $90 \mathrm{Sr}$ ) and Radiocesium ( $137 \mathrm{Cs}$ ) Using Giant Milky Weed (Calotropis Gigantea R.Br.) Plants. Chemosphere 2006, 65 (11), 20712073.

(44) Tsezos, M.; Keller, D. M. Adsorption of Radium-226 by Biological Origin Absorbents. Biotechnol. Bioeng. 1983, 25, 201-215.

(45) Zakeri, F.; Noghabi, K. A.; Sadeghizadeh, M.; Kardan, M. R.; Masoomi, F.; Farshidpour, M. R.; Atarilar, A. Serratia Sp. ZF03: An Efficient Radium Biosorbent Isolated from Hot-Spring Waters in High Background Radiation Areas. Bioresour. Technol. 2010, 101 (23), 9163-9170.

(46) IAEA. Various. Treat. Liq. Effl. from uranium mines mills 2004, No. October, 246 p.

(47) Heidari, F.; Riahi, H.; Aghamiri, M. R.; Shariatmadari, Z.; Zakeri, F. Isolation of an Efficient Biosorbent of Radionuclides (226Ra,238U): Green Algae from HighBackground Radiation Areas in Iran. J. Appl. Phycol. 2017, 29 (6), 2887-2898.

(48) Chao, J. H.; Chuang, C. Y. Accumulation of Radium in Relation to Some Chemical Analogues in Dicranopteris Linearis. Appl. Radiat. Isot. 2011, 69 (1), 261-267.

(49) Entry, J. A.; Watrud, L. S.; Reeves, M. Influence of Organic Amendments on the Accumulation of $137 \mathrm{Cs}$ and $90 \mathrm{Sr}$ from Contaminated Soil by Three Grass Species. Water. Air. Soil Pollut. 2001, 126 (3-4), 385-398.

(50) Fuhrmann, M.; Lasat, M. M.; Ebbs, S. D.; Kochian, L. V.; Cornish, J. Uptake of Cesium-137 and Strontium-90 from Contaminated Soil by Three Plant Species; Application to Phytoremediation. J. Environ. Qual. 2017, 31 (3), 904.

(51) Ragon, M.; Restoux, G.; Moreira, D.; Møller, A. P.; López-García, P. SunlightExposed Biofilm Microbial Communities Are Naturally Resistant to Chernobyl Ionizing-Radiation Levels. PLoS One 2011, 6 (7). 
(52) Lusa, M.; Knuutinen, J.; Lindgren, M.; Virkanen, J.; Bomberg, M. Microbial Communities in a Former Pilot-Scale Uranium Mine in Eastern Finland - Association with Radium Immobilization. Sci. Total Environ. 2019, 686, 619-640.

(53) Enyedi, N. T.; Anda, D.; Borsodi, A. K.; Szabó, A.; Pál, S. E.; Óvári, M.; Márialigeti, K.; Kovács-Bodor, P.; Mádl-Szőnyi, J.; Makk, J. Radioactive Environment Adapted Bacterial Communities Constituting the Biofilms of Hydrothermal Spring Caves (Budapest, Hungary). J. Environ. Radioact. 2019, 203 (March), 8-17. 


\section{Sequestration of radionuclides Radium-226 and Strontium-90 by}

\section{2 cyanobacteria forming intracellular calcium carbonates}

3 Neha Mehta $^{1}$, Karim Benzerara $^{2}$, Benjamin D. Kocar ${ }^{1,3^{*}}$, Virginie Chapon ${ }^{4}$

$4 \quad{ }^{1,3}$ Department of Civil and Environmental Engineering, Massachusetts Institute of Technology, Cambridge, 5 Massachusetts 02139, United States

$6 \quad{ }^{2}$ Sorbonne Université, Muséum National d'Histoire Naturelle, UMR CNRS 7590, Institut de Minéralogie, de 7 Physique des Matériaux et de Cosmochimie, IMPMC, 75005 Paris, France

8 3. Exponent, Inc. 1055 E. Colorado Blvd, Suite 500. Pasadena, California 91106, United States.

$9{ }^{4}$ CEA, CNRS, Aix-Marseille Université, UMR 7265 Biosciences and Biotechnologies Institute of Aix10 Marseille, 13108 Saint-Paul-lez-Durance, France.

$11 *$ Corresponding Author

134 Pages; 5 figures 


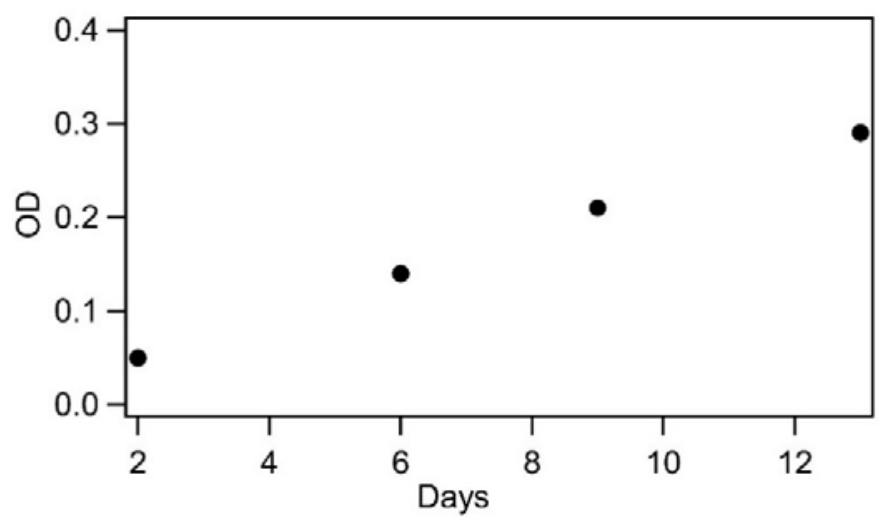

16 Saturation Indices calculation:

17 Visual MINTEQ (3.0) software package was used to calculate saturation indices of the culture 18 medium with several possible $\mathrm{Ca}$ and $\mathrm{Sr}$ solids based on the bulk chemical analyses. The 19 cultures were assumed to be in free exchange with the atmosphere with a partial $\mathrm{CO}_{2}$ pressures 20 of 3.5 atm. Using multi-sweep analysis, saturation indices were calculated for all Ca21 carbonate phases reported in the Visual MINTEQ database as a function of dissolved Ca concentration at fixed $\mathrm{pH}$ of 8 , for cultures amended with ${ }^{226} \mathrm{Ra}$. In contrast, saturation indices for all $\mathrm{Ca}$ and Sr solids reported in Visual MINTEQ database were calculated as a function of $24 \mathrm{pH}$ and fixed dissolved $\mathrm{Ca}^{2+}$ for cultures amended with ${ }^{90} \mathrm{Sr}$. 
Figure S2: The saturation indices of the solution with Ca-carbonate solids that may possibly remove ${ }^{226} \mathrm{Ra}$ are plotted as a function of dissolved total $\mathrm{Ca}$ concentration (at fixed $\mathrm{pH}=8$ )

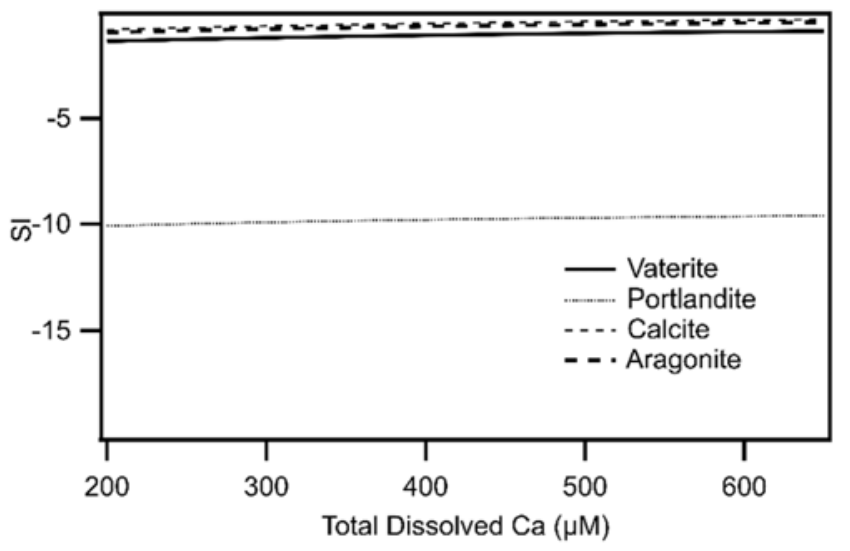

29 Figure S3: The saturation indices of the solution with $\mathrm{Ca}$ and $\mathrm{Sr}$ carbonate solids that may 30 possibly remove ${ }^{90} \mathrm{Sr}$ from solution, are plotted as a function of solution $\mathrm{pH}$ (at fixed total 31 dissolved $\left.\mathrm{Ca}^{2+}=250 \mu \mathrm{M}\right)$.

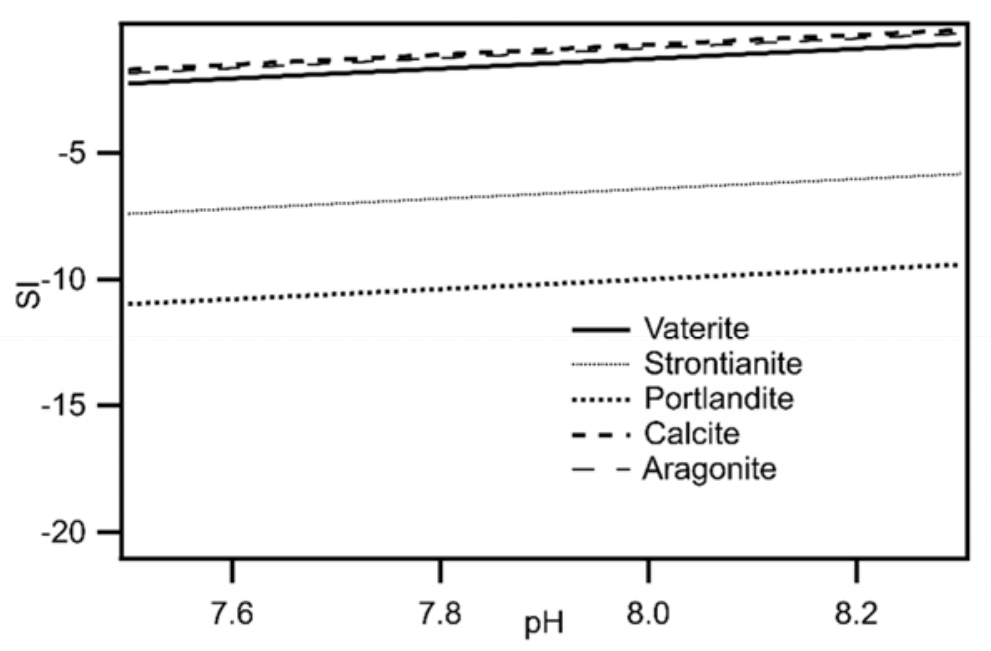


Figure S4: Cell grown in BG-11 amended with $210 \mathrm{kBq} \mathrm{L}-1{ }^{226} \mathrm{Ra}$, and $6.32 \times 10^{-4} \mathrm{M}$ Ca. The squares

34 denote residual ${ }^{226} \mathrm{Ra}$ activity in the solution and circles denote OD of the cell suspension.

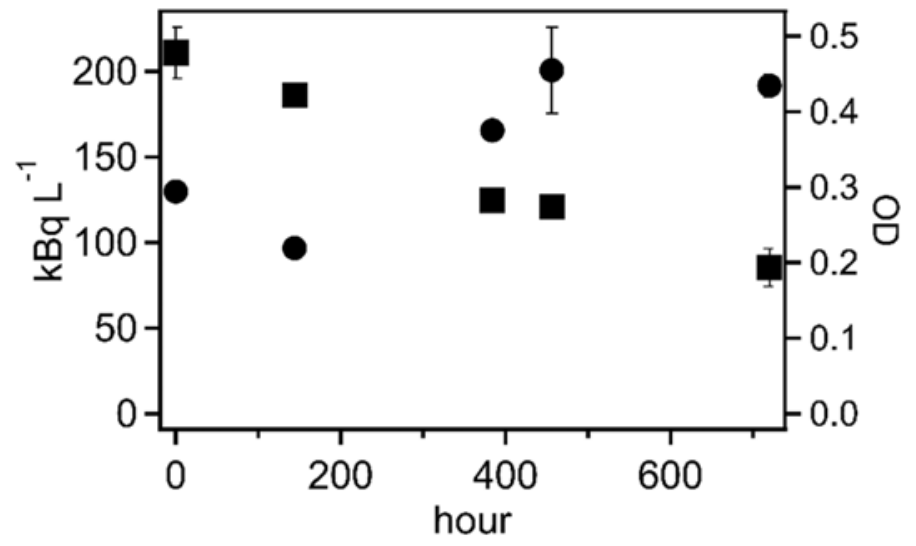

Figure S5: G. lithophora cells suspended at $\mathrm{OD}=0.5$ in BG- 11 amended with ${ }^{90} \mathrm{Sr}$. The BG11 was successively spiked with ${ }^{90} \mathrm{Sr}$ to measure maximum uptake of ${ }^{90} \mathrm{Sr}$ by G. lithophora.

39 The total amount of ${ }^{90} \mathrm{Sr}$ uptake measured $160 \mathrm{kBqL}^{-1}\left(40 \mathrm{kBqL}^{-1}\right.$ per spike), which considering an OD of 0.5 equals to $924 \mathrm{kBq}$ (g of biomass) $)^{-1}$

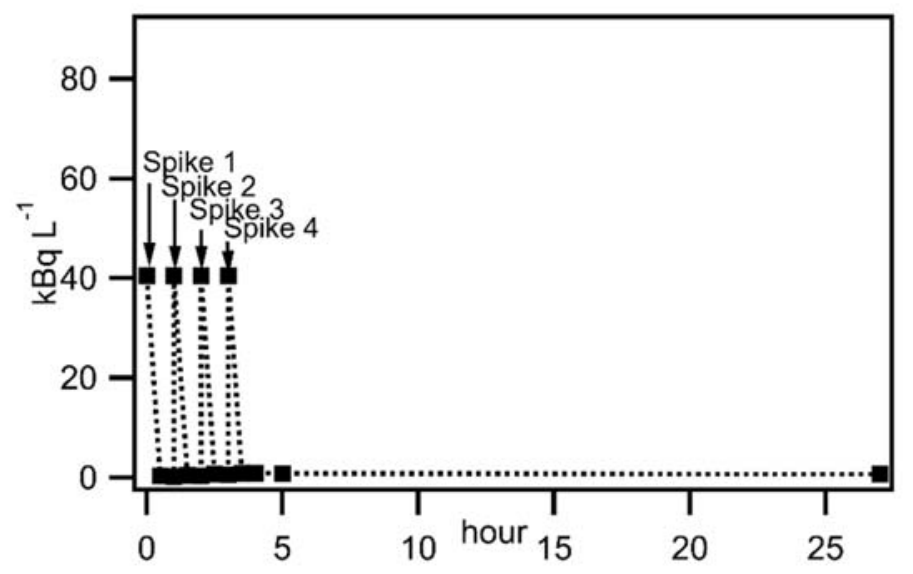

